PERANCANGAN KUALITAS PELAYANAN RUMAH SAKIT...... |.....RUDY JOEGIJANTORO

\title{
PERANCANGAN KUALITAS PELAYANAN RUMAH SAKIT MELALUI PENERAPAN FUZZY QUALITY FUNCTION DEPLOYMENT
}

\author{
Rudy Joegijantoro, M N Lisan Sediawan \\ STIKES Widyagama Husada
}

\begin{abstract}
Quality Function Deployment (QFD) is defined as a method that supports the structured design of products or services. The method is based on the customer needs and involves all the relevant parties within an organization that develops and produces a product through teamwork. It is a method for mapping and prioritizing customer requirements into functional features and technical modules to optimize market performance. Although the quality of a service can be dramatically improved through a QFD exercise, the traditional crisp scoring approach has a major drawback. A wrong conclusion can be easily produced since the fuzzy nature of linguistic correlation terms from evaluation members is ignored. To overcome this problem, fuzzy scoring for linguistic terms is proposed in this paper. This study integrates fuzzy logic into House Of Quality to establish a framework for prioritizing customer requirements to simply, objectively, and scientifically analyze service features.

Keywords: Quality Function Deployment, House Of Quality, Fuzzy Logic, Customer Requirements, Service Features
\end{abstract}




\section{ABSTRAK}

Quality Function Deployment (QFD) didefinisikan sebagai suatu metode yang mendukung desain terstruktur dari produk atau jasa. Metode ini didasarkan pada kebutuhan pelanggan dan melibatkan semua pihak terkait dalam sebuah organisasi yang mengembangkan dan memproduksi produk/jasa melalui kerja sama tim. Ini adalah metode untuk pemetaan dan memprioritaskan kebutuhan pelanggan ke dalam fitur fungsional dan modul teknis untuk mengoptimalkan kinerja pasar. Meskipun kualitas pelayanan dapat ditingkatkan secara dramatis melalui QFD, kita harus berhati-hati jika melaksanakan pendekatan penilaian secara tradisional karena seringkali memiliki kelemahan besar. Sebuah kesimpulan yang salah dapat dengan mudah terjadi jika mengabaikan sifat alamiah yang bersifat "fuzzy" dari korelasi linguistik anggota evaluasi diabaikan. Untuk mengatasi masalah ini, penilaian fuzzy untuk istilah linguistik diusulkan dalam tulisan ini. Penelitian ini mengintegrasikan logika fuzzy ke Rumah Kualitas untuk menyusun suatu kerangka kerja yang memprioritaskan kebutuhan pelanggan untuk secara mudah, objektif, dan ilmiah

\section{Kata Kunci: Quality Function Deployment, House Of Quality, Fuzzy Logic, Customer Requirements, Service Features}

\section{PENDAHULUAN \\ Latar Belakang}

Dalam era globalisasi saat ini persaingan bisnis menjadi sangat tajam, baik di pasar domestik (nasional) maupun di pasar internasional atau global. Untuk memenangkan persaingan, perusahaan harus mampu memberikan kepuasan kepada para pelanggannya, misalnya dengan memberikan produk yang lebih bermutu, lebih murah, dan pelayanan yang lebih baik daripada pesaingnya. Suatu produk dikatakan bermutu apabila dapat memenuhi kebutuhan pelanggannya. Oleh karena itu, pengetahuan tentang keinginan pelanggan (customer requirements) sangatlah penting.

Kepuasan pelanggan merupakan kunci sukses memenangkan persaingan. Hal ini tentu saja tidak mudah bagi pengelola rumah sakit, mengingat pelayanan yang diberikan juga menyangkut hidup para pasien / pelanggannya. Kepuasan pelanggan tidak hanya ditentukan oleh tindakan medis, ada banyak dimensi mutu lain yang mempengaruhi kepuasan pelanggan seperti: layanan administratif, keramahan dan ketanggapan para staf medis dan non medis, kemudahan, kecepatan \& ketepatan waktu layanan, dan lain sebagainya. Banyaknya dimensi mutu rumah sakit yang perlu diperhatikan sehingga penanganannya harus dilakukan dengan serius, cermat dan tepat.

Mutu pelayanan kesehatan seperti di rumah sakit, merupakan suatu fenomena yang unik, sebab dimensi dan indikatornya dapat berbeda diantara orang-orang yang terlibat dalam pelayanan kesehatan. Menurut Azwar (1996), untuk mengatasi perbedaan diatas seyogyanya yang dipakai sebagai pedoman adalah hakikat dasar dari penyelenggaraan pelayanan kesehatan, yaitu memenuhi kebutuhan dan tuntutan para pemakai jasa pelayanan kesehatan. Jadi, mutu pelayanan menunjuk pada tingkat kesempurnaan pelayanan kesehatan dalam memenuhi kebutuhan dan tuntutan setiap pasien. Dengan demikian, yang dimaksud dengan mutu pelayanan kesehatan adalah yang menunjukkan pada tingkat kesempurnaan pelayanan kesehatan dalam menimbulkan rasa puas pada diri setiap pasien.

Berdasarkan uraian diatas dapat disimpulkan bahwa determinan utama kepuasan pasien terhadap pelayanan kesehatan di rumah sakit adalah pemenuhan kebutuhan pasien, berupa pelayanan kesehatan yang dinilai bermutu. Harus disadari bahwa tujuan utama kegiatan di rumah sakit adalah melayani pasien dan juga keluarganya, dalam berbagai bentuk pelayanan. Davidson dan Ress-Mogg dalam bukunya The Great Reckoning (1993) menyatakan bahwa masyarakat luas di Amerika Serikat beranggapan bahwa mendapatkan pelayanan kesehatan yang bermutu adalah merupakan "hak" mereka. Buku terkenal lainnya, yakni "Megatrend 2001" oleh John Naisbitt dan Patricia Aburdene (1990) juga menyatakan bahwa semboyan "pelanggan adalah raja" kini sudah tiba saatnya. Kini adalah saatnya memperhatikan pelanggan, semua institusi, termasuk rumah sakit, harus berorientasi kepada kepuasan pelanggan. 
Dengan berorientasi pada customer dan kualitas sebagai dasar kegiatan dan landasan untuk bersaing, rumah sakit akan mampu mendapatkan profitabilitas jangka panjang yang diperoleh dari kepuasan pasien. Hal ini disebabkan karena dengan tingkat kepuasan tertentu, pasien akan bersedia menjalin ikatan jangka panjang dengan pihak rumah sakit yang saling menguntungkan kedua belah pihak (pasien dan rumah sakit). Peluang untuk mendapatkan profitabilitas masih terbuka lebar, hal ini ditunjang dari pertumbuhan jumlah penduduk $\pm 1,67 \%$ (1997) dan proporsi GDP untuk belanja sektor kesehatan sebesar 1,8\% (Dono Widiatmoko dan Ascobat Gani, 1999) serta tingkat pendapatan per kapita Indonesia saat ini, yang diperkirakan sekitar US\$ 4.000, dihitung berdasarkan Purchasing Power Parity (PPP) - nilai dolar tahun 2001(Kadin, 2007).

Dalam penelitian ini difokuskan terhadap pelayanan poliklinik rawat jalan di rumah sakit dengan latar belakang bahwa unit pelayanan poliklinik rawat jalan ini merupakan "wajah" yang sesungguhnya atau mewakili keseluruhan performa dari pelayanan kesehatan di suatu rumah sakit. Disisi lain, pelayanan poliklinik rawat jalan memberikan konstribusi yang cukup besar terhadap pendapatan rumah sakit.

Dari seluruh uraian diatas, untuk meningkatkan nilai kompetitif layanan rumah sakit, terutama layanan poliklinik rawat jalan maka suatu rumah sakit perlu mengembangkan pelayanan bermutu yang mampu memenuhi atau bahkan melampaui harapan pelanggan. Ada sebuah metode yang dapat dipakai untuk mengembangkan mutu pelayanan berorientasi pelanggan, yakni QFD. Quality Function Deployment (QFD) adalah suatu prosedur untuk mengidentifikasi, mengkomunikasikan, dan memprioritaskan persyaratan pelanggan, sehingga organisasi dapat mengoptimalkan produk atau jasa agar memenuhi harapan pelanggan. Oleh Foster, persyaratan pelanggan tersebut diterjemahkan dalam model the house of quality agar menjadi desain yang fungsional. Metode QFD dapat menghemat 33\% biaya dan $50 \%$ waktu, serta merupakan proses pengembangan desain mutu yang berkesinambungan dan koheren.

Penelitian ini berusaha untuk mengidentifikasi kebutuhan dan keinginan dari customer terhadap pelayanan poliklinik RS.Paru Batu agar dapat dikembangkan suatu layanan poliklinik yang sesuai dengan harapan dan keinginan pasien dengan menggunakan Quality Function Deployment. Metode QFD dipilih karena berawal dari suara pelanggan dan seluruh aspek pengembangan desain mutu mendasarkan pada kebutuhan pelanggan.

\section{Perumusan Masalah}

Dari uraian diatas, maka masalah dalam penelitian ini dapat dirumuskan sebagai berikut:

1. Kebutuhan riel apa saja yang dikehendaki oleh pelanggan terhadap pelayanan yang ditawarkan di instalasi rawat jalan RS Permata Bunda

2. Respon teknis atau fitur-fitur apa saja yang perlu disediakan oleh lnstalasi rawat jalan agar dapat memenuhi keinginan dan kebutuhan pelanggan?

\section{Tujuan Penelitian}

Tujuan yang hendak dicapai dalam penelitian ini dapat dirumuskan sebagai berikut:

1. Untuk mengetahui kebutuhan riel atau yang sesungguhnya dari pelanggan terhadap pelayanan instalasi rawat jalan RS. Permata Bunda.

2. Mengetahui respon teknis atau fitur-fitur yang perlu disediakan bagi instalasi rawat jalan agar mampu memenuhi keinginan dan kebutuhan pelanggannya.

\section{Manfaat Penelitian}

Manfaat yang diharapkan dari hasil penelitian ini adalah sebagai berikut:

1. Hasil penelitian ini bisa menjadi masukan bagi rumah sakit berupa metode untuk mengidentifikasi harapan dan keinginan pelanggan terhadap pelayanan Rumah Sakit.

2. Terbentuk suatu alat bantuuntuk mendesain layanan yang "customer oriented" sehingga dapat digunakan untuk meningkatkan pelayanan mereka kepada pelanggannya.

3. Hasil penelitian ini dapat digunakan sebagai referensi untuk pengembangan penelitian selanjutnya.

\section{METODE PENELITIAN}

\section{HASIL YANG DICAPAI}




\section{Gambaran Umum Rumah Sakit Permata}

BundaRumah Sakit Permata Bunda Malang merupakan rumah sakit swasta tipe $\mathrm{C}$ yang berdiri sejak 2001. Pada awal berdiri dikhususkan untuk melayani persalinan, namun seiring dengan perjalanan waktu juga melayani penyakit umum. Saat ini Rumah Sakit Permata telah memiliki akreditasi untuk beberapa pelayanannya. Fasilitas pelayanan yang dimiliki Rumah Sakit Permata Bunda diantaranya adalah poli bedah, poli kandungan dan kebidanan, poli anak, UGD, kamar operasi, poli gigi, poli penyakit dalam, neonatologi, laboratorium klinik, radiologi, apotek rumah sakit, instalasi rawat inap dan pavilion. Jumlah tempat tidur 50 buah.

Sumberdaya manusia yang melayani terdiri atas dokter umum 7 orang, spesialis obstetric ginekologi 2 orang, spesialis anak 2 orang, spesialis bedah 1 orang, spesialis penyakit dalam 1 orang, apoteker 1 orang dan perawat 35 orang. Menurut Pedoman Standarisasi Rumah Sakit Umum Kelas C yang diterbitkan oleh Depkes RI tahun 1994, ketenagaan di Poli rawat jalan Rumah Sakit Permata Bunda sebenarnya masih belum memenuhi kriteria. Jumlah SDM ini berpengaruh terhadap pengaturan jadwal bagi tenaga medis maupun paramedis.

Proses Kerja :

Alur pelayanan berawal dari pasien mendaftar di loket pendaftaran. Setelah proses pendaftaran selesai, pasien menunggu di ruang tunggu yang telah disediakan. Pelayanan medis diterima pasien setelah pasien dipanggil sesuai dengan nomor urut. Pasien bisa pulang setelah memperoleh pengobatan atau dirawatinapkan bila ada indikasi medis.

\section{Profil Responden}

Tabel Distribusi Responden Menurut Umur

\begin{tabular}{ccc}
\hline Umur & Frekwensi & $\begin{array}{c}\text { Persent } \\
\text { ase }\end{array}$ \\
\hline $17-25$ & 9 & $9 \%$ \\
$26-34$ & 22 & $22 \%$ \\
$35-43$ & 23 & $23 \%$ \\
$44-52$ & 14 & $14 \%$ \\
$53-61$ & 12 & $12 \%$ \\
$62-70$ & 10 & $10 \%$ \\
$71-79$ & 8 & $8 \%$ \\
$80-88$ & 2 & $2 \%$ \\
Jumlah & 100 & $100 \%$
\end{tabular}

Sumber : Diolah dari kuesioner responden (2013) Tingkat Pendidikan
Tabel Distribusi responden menurut tingkat pendidikan

\begin{tabular}{lll}
\hline \multicolumn{1}{c}{ Pendidikan } & Frekwensi & Persentase \\
\hline $\begin{array}{l}\text { Tidak sekolah / tidak } \\
\text { tamat SD }\end{array}$ & 9 & $9 \%$ \\
Tamat SD & 20 & $20 \%$ \\
Tamat SLTP & 28 & $28 \%$ \\
Tamat SLTA & 37 & $37 \%$ \\
Sarjana Muda/Diploma & 3 & $3 \%$ \\
Sarjana & 3 & $3 \%$ \\
Pascasarjana & 0 & $0 \%$ \\
\hline Jumlah & 100 & $100 \%$ \\
\hline Sumber : Diolah dari kuesioner responden $(2013)$ \\
Pekerjaan
\end{tabular}

Distribusi Responden Menurut Jenis Pekerjaan

\begin{tabular}{|c|c|c|}
\hline Jenis Pekerjaan & Frekwensi & Persentase \\
\hline TNI / POLRI & 2 & $2 \%$ \\
\hline Pegawai Negeri & 10 & $10 \%$ \\
\hline $\begin{array}{l}\text { Pedagang / } \\
\text { Wiraswasta }\end{array}$ & 13 & $13 \%$ \\
\hline $\begin{array}{l}\text { Buruh / tukang / } \\
\text { tani }\end{array}$ & 22 & $22 \%$ \\
\hline Pegawai Swasta & 26 & $26 \%$ \\
\hline Lain-lain & 27 & $27 \%$ \\
\hline Jumlah & 100 & $100 \%$ \\
\hline \multicolumn{3}{|c|}{$\begin{array}{l}\text { Sumber : Diolah dari kuesioner responden (2013) } \\
\text { Pendapatan Keluarga }\end{array}$} \\
\hline $\begin{array}{l}\text { Distribusi Responer } \\
\text { Keluarga }\end{array}$ & nurut Pen & atan \\
\hline
\end{tabular}

\begin{tabular}{lcc}
\hline \multicolumn{1}{c}{ Jenis Pekerjaan } & Frekwensi & Persentase \\
\hline$<$ Rp.1.000.000 & 70 & $70 \%$ \\
Rp.1.000.000- & 30 & $30 \%$ \\
Rp.2.000.000 & & \\
Rp.2.000.000- & 0 & 0 \\
Rp.3.000.000 & & \\
Rp.3.000.000- & 0 & 0 \\
Rp.4.000.000 & & \\
Rp.4.000.000- & 0 & 0 \\
$\begin{array}{l}\text { Rp.5.000.000 } \\
\text { > Rp.5.000.000 }\end{array}$ & 0 & 0 \\
\hline Jumlah & 100 & 100 \\
\hline $\begin{array}{l}\text { Sumber : Diolah dari kuesioner responden }(2013) \\
\text { Tingkat kepentingan dan Tingkat Kepuasan } \\
\text { pasien }\end{array}$
\end{tabular}

Dari data pada tabel diatas dapat diketahui bahwa pasien memiliki kepuasan untuk tiap atribut dalam dimensi Tangibles (Penampilan fisik karyawan, perawat, dokter saat memberikan 
pelayanan, Kemutakhiran peralatan medis yang digunakan dalam melayani , Kenyamanan, kebersihan, dan keindahan lingkungan serta fasilitas fisik, Ketersediaan tempat parkir, dan Penampilan fasilitas fisik sesuai dengan jenis jasa yang diberikan ) rata-rata diatas netral namun belum sampai membuat pasien puas. Sedangkan tingkat kepentingan terhadap dimensi yang bersangkutan beserta atribut-atributnya rata-rata diatas penting hingga sangat penting. Dari data tersebut bisa diambil kesimpulan bahwa pihak rumah sakit perlu lebih memperhatikan faktor tangibilitas dalam upaya meningkatkan kualitas pelayanannya.

Tingkat kepuasan terhadap dimensi Reliability (Ketepatan waktu pelayanan sesuai dengan jadwal yang diberikan, Keteraturan / ketertiban alur pelayanan, Pemeriksaan pasien dilayani oleh dokter yang sesuai, Keakuratan penanganan / pengadministrasian catatan/dokumen pasien oleh RS) rata-rata diatas netral bahkan mendekati puas namun salah satu atribut, yakni ketepatan waktu pelayanan belum bisa memberikan kepuasan bagi pasien. Dilain pihak, pasien memiliki kepentingan untuk tiap atribut dalam dimensi Reliability ratarata bernilai diatas penting. Dengan demikian, pihak rumah sakit dituntut memperhatikan juga aspek reliabilitas pelayanan dalam upaya meningkatkan kualitas pelayanan.

Tingkat kepuasan terhadap dimensi Responsiveness (lamanya menunggu diperiksa dokter, kejelasan informasi penyampaian layanan medis, kesediaan petugas dalam memberikan layanan dengan cepat, serta kesediaan petugas dalam membantu kesulitan yang dihadapi pasien) rata-rata diatas netralnamun belum bisa membuat pasien puas. Bila dibandingkan dengan tingkat kepentingannya yang rata-rata diatas penting, maka dapat disimpulkan bahwa rumah sakit perlu juga memperhatikan aspek dimensi responsiveness bila berkeinginan dalam meningkatkan kepuasan pelanggan.

Terhadap dimensi Assurance (keamanan dan keselamatan pasien diperhatikan, serta kemampuan petugas dalam menyimpan rahasia pasien) dari data diatas dapat diketahui bahwa pasien memiliki kepuasan untuk tiap atribut dalam dimensi tersebut rata-rata diatas netral namun masih belum dicapai tingkat kepuasan yang diharapkan. Pasien memiliki kepentingan untuk tiap atribut dalam dimensi Assurance ratarata diatas nilai penting, artinya semua atribut Assurance dianggap penting oleh pasien.
Dari data diatas juga dapat dilihat bahwa pasien memiliki kepuasan untuk tiap atribut dalam dimensi Competence (kemampuan dan keterampilan petugas dalam melayani / menangani pasien, kemampuan petugas dalam menjawab setiap pertanyaan pasien, serta pengalaman dan pengetahuan dokter dalam memeriksa pasien) rata-rata diatas netral dan hampir mendekati nilai puas. Dapat diambil kesimpulan bahwa pasien hampir puas terhadap tiap atribut dalam dimensi competence. Semua atribut dalam dimensi competence dianggap penting oleh pasien bahkan tingkat kepentingannya mendekati sangat penting.

Terhadap dimensi Courtesy(kesabaran petugas dalam memberikan pelayanan, dan kesopanan petugas dalam memberikan pelayanan) pasien memiliki tingkat kepuasan rata-rata diatas puas, yang artinya pasien puas terhadap masingmasing atribut dalam dimensi courtesy. Bila dilihat dari tingkat kepentingannya yang rata-rata diatas penting dan bahkan mendekati sangat penting, dapat disimpulkan bahwa rumah sakit telah dapat memberikan kepuasan terhadap pasiennya dari aspek dimensi courtesy.

Tingkat kepuasan terhadap dimensi communication (penggunaan bahasa yang mudah dipahami oleh pasien dalam berkomunikasi, penjelasan mengenai layanan yang diberikan, penyakit yang diderita, biaya yang dikenakan dan lain-lain, serta kesempatan untuk bertukar pikiran / mengemukakan masalah kepada petugas) ratarata menghasilkan nilai diatas netral, bahkan pada beberapa atribut (penggunaan bahasa yang mudah dipahami dan penjelasan mengenai layanan yang diberikan) mendekati nilai puas. Pasien memiliki kepentingan untuk tiap atribut dalam dimensi Communication rata-rata bernilai diatas penting. Dapat disimpulkan bahwa pasien menganggap penting (mendekati sangat penting) setiap atribut dalam dimensi communication.

Dari data pada tabel 4.6. diatas juga dapat diketahui bahwa pasien memiliki kepuasan untuk tiap atribut dalam dimensi Access (kemudahan untuk dijangkau dengan angkutan umum. kemudahan dihubungi lewat telepon, kemudahan untuk dicapai / ada tidaknya penghalang, serta kemudahan untuk membuat perjanjian dengan petugas pelayanan) rata-rata bernilai diatas netral. Kecuali atribut "kemudahan dijangkau angkutan umum" yang sudah memberikan kepuasan bagi pasien, atribut lainnya masih belum mampu membuat pasien puas. Pasien memiliki kepentingan untuk tiap atribut dalam dimensi 
Access rata-rata diatas penting. Jadi dapat disimpulkan bahwa pasien menganggap penting semua atribut dalam dimensi access.

Tingkat kepuasan untuk tiap atribut dalam dimensi Caring (perhatian petugas terhadap permasalahan / kesulitan pasien, pemahaman petugas terhadap kebutuhan dan harapan pasien, serta kesediaan petugas meluangkan waktu untuk komunikasi dengan pasien)rata-ratabernilaidiatas puas. Jika dilihat dari tingkat kepentingannya untuk tiap atribut dalam dimensi caring rata-rata bernilai diatas penting. Ini berarti bahwa pasien mengganggap semua atribut dalam dimensi caring adalah penting.

Terhadap dimensi Patient Outcome (kesembuhan terhadap penyakit yang diderita pasien dan biaya yang dikeluarkan untuk memperoleh pelayanan) pasien memiliki tingkat kepuasan untuk tiap atribut dalam dimensi tersebut rata-rata bernilai diatas netral. Dari data pada tabel diatas dapat diketahui bahwa pasien memiliki kepentingan untuk tiap atribut dalam dimensi Patient Outcome rata-rata diatas penting. Artinya bahwa pasien mengganggap bahwa semua atribut dalam dimensi patient outcome adalah penting, bahkan atribut "kesembuhan terhadap penyakit yang diderita" bernilai mendekati sangat penting bagi pasien.

Dari data pada tabel 4.6. diatas dapat diketahui bahwa pasien memiliki kepuasan untuk tiap atribut dalam dimensi Collaboration (antar petugas saling bekerja sama dalam melayani pasien, serta pekerjaan yang dilaksanakan antar petugas tidak tumpang tindih) rata-rata bernilai diatas netral. Namun demikian tiap-tiap atribut dalam dimensi collaboration belum mampu memberikan kepuasan bagi pasien. Jika dilihat dari tingkat kepentingannya, pasien menilai bahwa tiap atribut dalam dimensi collaboration rata-rata diatas penting. Hal ini berarti pasien menganggap penting semua atribut dalam dimensi collaboration.

Dari ulasan diatas bisa ditarik kesimpulan bahwa sebagian besar pasien belum memiliki kepuasan untuk tiap atribut(masih berkisar diantara netral hingga puas) dan hanya 3 buah atribut saja yang mampumemberikan kepuasan bagi pasien, yakni atribut "kesabaran petugas", "kesopanan petugas", serta "kemudahan dijangkau oleh angkutan umum". Bahkan untuk keseluruhan atribut tidak ada pasien yang tergolong sangat puas. Namun demikian, tidak ada pasien yang tergolong tidak puas atau sangat tidak puas terhadap tiap atribut produknya.

\section{Indeks Kepuasan}

Untuk mengetahui seberapa besar kemampuan rumah sakit dalam memuaskan pasiennya, digunakan analisis indeks kepuasan pelanggan. Analisis indeks kepuasan pelanggan ini dilakukan melalui dua tahap sebagai berikut :

Tahap pertama adalah menghitung faktor-faktor tertimbang seperti pada tabel berikut ini:

Tabel Faktor Tertimbang Berbagai Dimensi

\begin{tabular}{lcc}
\hline \multicolumn{1}{c}{ Dimensi } & $\begin{array}{c}\text { Rata-rata skor } \\
\text { pentingnya (RSP) }\end{array}$ & $\begin{array}{c}\text { Faktor tertimbang } \\
{[F T=(R S P /}\end{array}$ RSP) $\left.100 \%\right]$
\end{tabular}


Tahap kedua adalah menghitung indeks kepuasan pada tabel berikut ini:

Tabel .Skor Tertimbang Berbagai Dimensi

\begin{tabular}{cccc}
\hline Dimensi & $\begin{array}{c}\text { Rata-rata } \\
\text { skor kepuasan } \\
(\mathrm{RSP})\end{array}$ & $\begin{array}{c}\text { Faktor } \\
\text { Tertimbang } \\
(\mathrm{FT})\end{array}$ & $\begin{array}{c}\text { Skor } \\
\text { tertimbang } \\
{[S T=(\text { RSPXF }} \\
\text { T)] }\end{array}$ \\
\hline Tangibles & 3,6 & $9,0 \%$ & 0,324 \\
Reliability & 3,6 & $9,2 \%$ & 0,331 \\
Responsiveness & 3,4 & $9,2 \%$ & 0,313 \\
Assurance & 3,6 & $9,4 \%$ & 0,338 \\
Competence & 3,9 & $9,0 \%$ & 0,351 \\
Courtesy & 4,2 & $9,6 \%$ & 0,403 \\
Communication & 3,8 & $9,4 \%$ & 0,357 \\
Access & 3,6 & $9,0 \%$ & 0,324 \\
Caring & 3,4 & $9,0 \%$ & 0,306 \\
Patient outcome & 3,7 & $8,8 \%$ & 0,326 \\
Collaboration & 3,3 & $8,8 \%$ & 0,290 \\
\hline \multicolumn{5}{c}{ Jumlah } & & 3,664 \\
\hline
\end{tabular}

Indeks Kepuasan (IK) diperoleh dengan cara mengkalikan total skor tertimbang dengan 5 (karena skalanya berupa 5 nilai). Jadi Indeks kepuasan yang diperoleh sebesar : 3,664 × $5=$ $18,319 \%$. Indeks kepuasan sebesar 18,319\% menunjukkan bahwa rumah sakit (instalasi) hanya berhasil memuaskan sebanyak 18,319 \% pasiennya.

Implikasi dari hasil diatas adalah bahwa rumah sakit perlu bekerja keras untuk memperbaiki kualitas pelayanannya sehingga akan lebih banyak pasien yang tergolong puas atau sangat puas.

\section{Perancangan Rumah Kualitas (House of Quality)}

Berdasarkan hasil diatas, jelas bahwa ada kesenjangan antara kinerja yang telah dihasilkan oleh pelayanan rawat jalan Rumah Sakit Permata Bunda dengan harapan pelanggannya. Untuk itu, perlu dibuatkan suatu model pelayanan yang mampu menangkap keseluruhan harapan pelanggan dan mewujudkannya sesuai dengan harapan tersebut melalui perancangan rumah kualitas dengan tahapan-tahapan sebagai berikut :

\section{Penentuan Prioritas Persyaratan Pelanggan}

Untuk menentukan apa saja persyaratan pelanggan yang penting untuk peningkatan kualitas melalui House of Quality peneliti menggunakan metode Satisfaction - Importance Quadrant. Konsep ini merupakan adaptasi dari Satisfaction - Importance Matrix dari Alan Dutka (1994). Konsep sederhana mengenai Satisfaction Importance Quadrant bisa dijelaskan sebagai berikut :
Untuk menentukan prioritas perbaikan kualitas atribut (atau dimensi) suatu layanan digunakan gambar yang terdiri dari empat kuadran. Tingkat pentingnya suatu atribut dibuat pada sumbu horisontal dan tingkat kepuasan suatu atribut pada sumbu vertikal.

Penempatan atribut pada kuadran diatas berdasarkan rata-rata skor tingkat kepuasan dan rata-rata skor tingkat kepentingan dari atribut yang bersangkutan.Analisis dari kuadran diatas adalah :

a) Atribut yang berada pada kuadran kiri-bawah (low priority) menunjukkan atribut itu tidak penting dan kinerjanya rendah (sedikit memberikan kepuasan bagi pasien). Atribut atribut ini tidak terlalu masalah meskipun tidak diperbaiki. Dalam penelitian ini, tidak ada yang termasuk dalam atribut jenis low priority.

b) Atribut yang berada pada kiri-atas (Unnecessary strengths) menunjukkan bahwa atribut tersebut kurang penting namun memberikan kepuasan yang tinggi bagi pasien. Rumah sakit memberikan pelayanan yang berlebihan sehingga menguras sumber daya, diharapkan di masa yang akan datang, sumber daya yang digunakan untuk atribut atribut ini dimungkinkan untuk dialokasikan untuk memperbaiki kualitas atribut - atribut yang berada di bawah-kanan (Attributes that need attention / High Priority). Dalam penelitian ini, tidak ada yang termasuk dalam atribut jenis Unnecessary strengths. 
c) Atribut yang berada pada kanan-bawah (Attributes that need attention / High Priority) menunjukkan bahwa atribut tersebut penting tetapi kinerjanya rendah (tingkat kepuasan pasien yang dicapai rendah). Atribut yang demikian sangat perlu untuk diperbaiki atau ditingkatkan kualitasnya. Dalam penelitian ini, yang termasuk dalam atribut jenis High Priority (diurut berdasarkan skor kesenjangan/gap).

Makin besar kesenjangannya makin tidak puas pasien. Implikasinya adalah makin besar skor kesenjangan suatu atribut makin perlu atribut itu dijadikan prioritas perbaikan. Atribut lamanya menunggu diperiksa dokter, ketepatan waktu pelayanan serta ketersediaan tempat parkir yang nyaman berturut-turut merupakan tiga atribut utama yang menjadi prioritas yang dipertimbangkan konsumen.

Atribut yang berada pada kuadran kanan-atas (Current Organization Strengths) menunjukkan atribut tersebut penting dan kinerjanya juga tinggi (derajat kepuasan yang tinggi). Atribut yang demikian perlu dipertahankan oleh manajemen rumah sakit. Dalam penelitian ini, yang termasuk dalam atribut jenis Current Organization Strenghts adalah : Cr1 (kesabaran petugas), Cr2 (kesopanan petugas), serta Acc1 (kemudahan dijangkau oleh angkutan umum) .

\section{Penentuan respon atau persyaratan teknis}

Setelahberhasil mengidentifikasi persyaratan pelanggan, analisis berikutnya adalah mengidentifikasi karakteristik / persyaratan teknis. Karakteristik teknis yang berhasil dihimpun melalui focus group discussion dengan pihak manajemen rumah sakit adalah sebagai berikut :

1) Kinerja tenaga dokter, meliputi :

- Kecepatan / tanggapan dokter dalam menangani pasien

- Pengetahuan dan skill medis

- Kesabaran dokter terhadap pasien

- Penampilan profesional

2) Kinerja tenaga perawat, meliputi :

- Kecakapan tenaga perawat dalam melaksanakan asuhan keperawatan

- Kemampuan bekerja sama dengan dokter

- Perhatian, kesabaran, dan ketelatenan kepada pasien

- Penampilan profesional

3) Sarana dan prasarana, meliputi :

- Harga obat yang terjangkau pasien
- Tersedianya tempat parkir yang luas, aman dan nyaman

- Ruang tunggu yang nyaman

- Ruang periksa yang nyaman

- Peralatan medis yang modern

4) Manajemen, meliputi :

- Jadwal pelayanan yang tepat waktu sesuai dengan yang dijanjikan

- Sistem administrasi yang lebih mudah

- Biaya pelayanan

- Sistem reward dan punishment bagi tenaga medis dan paramedis

- Reputasi baik

\section{Penyusunan Planning Matrix}

Matriks Perencanaan disusun melalui tahapan berikut ini :

\section{Penyusunan Tingkat Kepentingan Pelanggan} (Kolom 1)

Tingkat kepentingan terhadap atribut-atribut persyaratan pelanggan diperoleh dari nilai ratarata skor kepentingan yang dinilai oleh responden (100 orang). Karena skala tingkat kepentingan memiliki rentang nilai antara $1-5$, maka tingkat kepentingan berada pada kisaran nilai tersebut. Dari hasil penelitian diperoleh tingkat kepentingan yang bervariasi diantara atributatribut persyaratan pelanggan (Lampiran 1).

Penyusunan Tingkat Kepuasan Pelanggan terhadap instalasi RS. Permata Bunda (Kolom 2), serta terhadap pesaing sejenis (kolom 3)

Tingkat kepuasan terhadap atribut-atribut persyaratan pelanggan diperoleh dari rata-rata skor kepuasan yang dinilai oleh responden (100 orang). Karena skala tingkat kepuasan memiliki rentang nilai antara $1-5$, maka tingkat kepuasan juga berada pada kisaran nilai tersebut. Dari hasil penelitian diperoleh tingkat kepuasan yang bervariasi diantara atribut-atribut persyaratan pelanggan (Lampiran 2).

\section{Penentuan Goal (kolom 4)}

Target yang hendak diraih diperoleh dengan cara memperhatikan nilai kinerja pelayanan dari pesaing (tingkat kepuasan terhadap pesaing) serta tingkat kepentingan dari masing-masing atribut. Hasil yang hendak dicapai memang masih dibawah nilai kepentingan yang diberikan, namun sudah diatas nilai kinerja (tingkat kepuasan) saat ini dan kinerja pesaing.Penentuan goal ini didasarkan kepada kemampuan rumah sakit dari segi sumberdaya dan pendanaan serta perencanaan yang telah dibuat.Walaupun demikian, goal ini bilamana tercapai masih 
mampu memberikan kepuasan pelanggan jauh lebih baik dibandingkan sebelumnya.

\section{Perhitungan Rasio Perbaikan (Improvement ratio) (kolom 5)}

Rasio perbaikan ini diperoleh dari pembagian antara Goal dengan tingkat kepuasan masingmasing atribut (Current Satisfaction Performance) . Dari hasil perhitungan didapatkan rasio perbaikan yang tidak seberapa besar, berkisar antara 1,1 hingga 1,2 (Lampiran 3). Artinya, rumah sakit tidak perlu mengeluarkan sumber daya dalam jumlah besar untuk memperbaiki performance pelayanannya.Rasio perbaikan bernilai 1 bila tidak ada perbaikan yang hendak dilakukan.Dari hasil ini rumah sakit dengan segala keterbatasan yang dimiliki sebenarnya hanya perlu melakukan sedikit saja perbaikan untuk memperoleh tingkat kepuasan yang tinggi dari pelanggannya.

\section{Penentuan Sales Point (kolom 6)}

Data ini berisi informasi tentang kemampuan dalam menjual produk/jasa berdasarkan seberapa baik customer need dapat dipenuhi. Dengan kata lain, nilai ini menggambarkan besar-kecilnya daya saing atribut layanan rumah sakit terhadap rivalnya.

Nilai yang paling umum digunakan pada sales pointadalah :

1 = tanpa sales point (tidak ada daya saing)

$1,2=$ Sales point menengah (daya saing kecil)

$1,5=$ Sales point kuat (daya saing tinggi)

Dari hasil diskusi yang mendalam dengan pihak rumah sakit didapatkan hasil sebagai berikut :

- Atribut yang memiliki sales point kuat atau memiliki daya saing tinggi adalah:

- Penampilan fisik tenaga medis maupun non medis dalam melayani pasien.

- Kemutakhiran peralatan medis

- Kenyamanan, kebersihan, dan keindahan lingkungan serta fasilitas fisik (ruang periksa, ruang tunggu, loket, bangunan, dll).

- Ketersediaan tempat parkir.

- Penampilan fasilitas fisik.

- Ketepatan waktu pelayanan.

- Pemeriksaan pasien dilayani oleh dokter yang sesuai.

- Waktu tunggu diperiksa dokter.

- Kesediaan petugas dalam memberikan3. layanan dengan cepat.

- Kemampuan dan keterampilan petugas dalam melayani / menangani pasien.

- Pengalaman dan pengetahuan dokter dalam memeriksa pasien.
- Perhatian petugas terhadap permasalahan / kesulitan pasien.

- Pemahaman petugas terhadap kebutuhan dan harapan pasien.

- Kesediaan petugas meluangkan waktu untuk komunikasi dengan pasien.

- Kesembuhan terhadap penyakit yang diderita.

- Biaya yang dikeluarkan untuk memperoleh pelayanan.

Atribut-atribut diatas merupakan atribut andalan bagi rumah sakit dalam menggaet pelanggan, namun demikian memiliki tingkat persaingan yang tinggi karena rumah sakit kompetitor juga memiliki upaya-upaya yang hampir mirip. Keberhasilan dalam mengelola atribut-atribut tersebut akan memberikan kontribusi yang besar dalam memenangkan persaingan.

2. Atribut yang memiliki sales point menengah atau memiliki daya saing kecil adalah :

- Keteraturan / ketertiban alur pelayanan (dari loket, poli, lab/radiologi, apotek dll)

- Keakuratan penanganan/pengadministrasian catatan/dokumen pasien oleh RS.

- Kejelasan informasi penyampaian layanan medis (prosedur pelayanan).

- Kesediaan petugas dalam membantu kesulitan yang dihadapi pasien.

- Kemampuan petugas dalam menyimpan rahasia pasien.

- Kesempatan untuk bertukar pikiran / mengemukakan masalah kepada petugas.

- Kemudahan dihubungi lewat telepon.

- Kemudahan untuk dicapai (tidak ada penghalang fisik untuk mencapai instalasi).

- Kemudahan untuk membuat perjanjian dengan petugas pelayanan.

Atribut-atribut yang masuk dalam kriteria ini memiliki tingkat persaingan yang lebih rendah daripada atribut-atribut yang telah disebut sebelumnya, karena belum banyak rumah sakit yang mampu mengelola dengan baik atributatribut ini. Persaingan dalam atribut ini tidak begitu ketat bila dibandingkan dengan sebelumnya namun pihak Rumah Sakit Permata Bunda harus selalu waspada karena pihak kompetitor akan selalu melakukan upaya-upaya perbaikan.

Atribut yang tidak memiliki sales point atau tidak memiliki daya saing adalah :

- Kemampuan petugas dalam menjawab setiap pertanyaan pasien. 
- Penggunaan bahasa yang mudah dipahami oleh pasien dalam berkomunikasi (terutama istilah medis).

- Penjelasan mengenai layanan yang diberikan, penyakit yang diderita, biaya yang dikenakan dll

- Antar petugas saling bekerja sama dalam melayani pasien.

- Pekerjaan yang dilaksanakan antar petugas tidak tumpang tindih.

Yang dimaksud tidak memiliki daya saing disini adalah bahwa atribut-atribut tersebut sama-sama dimiliki oleh Rumah Sakit Permata Bunda dan juga rumah sakit kompetitor dan telah dijalankan dengan sama baiknya. Penambahan sumberdaya atau perbaikan pada atribut ini tidak perlu dilakukan lagi sehingga bisa dialihkan untuk perbaikan atribut yang memiliki daya saing tinggi. Perhitungan Matriks interrelasi (Relationship Matrix)

Langkah selanjutnya dalam membangun House Of Quality adalah menyiapkan persyaratan pelanggan (kebutuhan dan keinginan pelanggan) dan karakteristik teknis untuk menentukan hubungan antara keduanya dalam sebuah matriks. Masing-masing hubungan digambarkan:

$$
\begin{array}{ll}
- & =\text { Hubungan Kuat }(\text { skor } 9) \\
\bigcirc & =\text { Hubungan moderat }(\text { skor } 3) \\
\triangle & =\text { Hubungan lemah }(\text { skor } 1)
\end{array}
$$

Cara mengisi matriks ini adalah dengan melihat hubungan antara masing-masing karakteristik WHAT (atribut / persyaratan pelanggan) dan HOW (karakteristik teknis) apakah terdapat hubungan atau tidak. Penentuan hubungan ini bisa melalui dua metode, yakni melalui metode crisp atau melalui metode fuzzy (skala linguistik) (Hauser dan Clausing, 1988, Cohen, 1995).

Dalam tesis ini, analisis hubungan dalam matriks interrelasi dikerjakan melalui dua pendekatan, yakni pendekatan Crisp dan pendekatan Fuzzy. Penentuan kekuatan hubungan antara WHAT dan HOW melalui metode crisp berdasarkan kesepakatan yang dihasilkan oleh focus group discussion antara pihak manajemen rumah sakit dengan peneliti. Bila keputusan kelompok dalam focus group discussion menghasilkan keputusan kekuatan hubungan adalah kuat, maka skor hubungan diberi nilai 9, sedangkan bila hasil keputusan kekuatan hubungan adalah sedang / moderat, maka skor hubungan diberi nilai 3, dan apabila hasil keputusan kelompok menilai hubungannya adalah lemah maka skor hubungan diberi nilai 1 .
Untuk menjaga konsistensi keputusan selama mengevaluasi keseluruhan hubungan dalam matriks interrelasi, maka penentuan skor kekuatan hubungan melalui focus group discussion berpegangan terhadap kaidah-kaidah sebagai berikut :

- Jika karakteristik teknis (HOW) merupakan kontributor yang kuat terhadap atribut kebutuhan pelanggan (WHAT), serta hubungan ini sangat penting keberadaannya dalam menggapai misi rumah sakit, maka kekuatan hubungannya disimpulkan kuat.

- Jika karakteristik teknis (HOW) merupakan kontributor yang sedang terhadap atribut kebutuhan pelanggan (WHAT), serta hubungan ini penting keberadaannya dalam menggapai misi rumah sakit maka kekuatan hubungannya disimpulkan sedang.

- Jika karakteristik teknis (HOW) merupakan kontributor yang kecil terhadap atribut kebutuhan pelanggan (WHAT), serta hubungan ini kurang penting keberadaannya dalam menggapai misi rumah sakit maka kekuatan hubungannya disimpulkan rendah.

- Jika tidak ada hubungan antara HOW dan WHAT, serta hubungan ini tidak berpengaruh dalam menggapai misi rumah sakit maka nilainya adalah 0 .

\section{Arah perbaikan}

Dari matrix House of Quality bagian plafon dapat dilihat arah perbaikan dari masing-masing atribut persyaratan teknis. Tanda panah keatas menandakan bahwa atribut memberikan pengaruh positif terhadap kualitas keseluruhan, sedangkan tanda panah kebawah memberikan pengaruh negatif bila tidak diperbaiki. Misalkan atribut biaya pelayanan, bila atribut biaya pelayanan diturunkan, akan memberikan dampak langsung kepada kepuasan pelanggan. Pelanggan akan memberikan apresiasi positif bila langkah ini dilakukan. Yang masuk kedalam golongan ini (tanda panah ke bawah) adalah 1) harga obat, 2) Jadwal pelayanan, serta 3) biaya.

\section{Korelasi Antar Persyaratan Teknis.}

Pada bagian puncak / atap dari House of Quality bisa dilihat korelasi antar persyaratan teknis. Korelasi positif kuat terjadi pada atribut kecepatan / ketanggapan dokter dengan pengetahuan dan skill dokter. Ini berarti bahwa pengetahuan dan skill dokter memberikan pengaruh yang kuat terhadap kecepatan dokter dalam mendiagnosa dan memberikan terapi kepada pasien. Hubungan yang kuat juga terjadi antara atribut pengetahuan dan skill dokter dengan atribut peralatan medis 
modern. Hal ini mengandung arti bahwa pengetahuan dan skill dokter memberikan pengaruh yang kuat terhadap penguasaan dokter terhadap pengoperasian peralatan medis yang modern, dan sebaliknya, penguasaan peralatan medis modern dibutuhkan pengetahuan dan skill dokter yang memadai. Hubungan yang kuat nampak pula terjadi pada atribut kecepatan dan ketanggapan dokter dengan atribut jadwal pelayanan. Hal in memberikan gambaran bahwa jadwal pelayanan dipengaruhi oleh kecepatan dokter dalam melayani pasiennya.

Korelasi positif juga terjadi antara :

- Atribut kecepatan / ketanggapan dokter dengan atribut kecepatan asuhan keperawatan.

- Atribut kecepatan / ketanggapan dokter dengan atribut kemampuan kerjasama perawat.

- Atribut kesabaran dokter dengan atribut perhatian dan kesabaran perawat.

- Atribut pengetahuan dan skill dokter, kesabaran dokter, penampilan profesional dokter dan perawat, kecakapan asuhan keperawatan dengan atribut reward dan punishment.

\section{KESIMPULAN}

Arah perbaikan yang perlu dilakukan oleh pihak rumah sakit menurut kebutuhannya ada dua macam, keatas dan kebawah. Tanda panah keatas menandakan bahwa atribut memberikan pengaruh positif terhadap kualitas keseluruhan, sedangkan tanda panah kebawah memberikan pengaruh negatif bila tidak diperbaiki. Misalkan atribut biaya pelayanan, bila atribut biaya pelayanan diturunkan, akan memberikan dampak langsung kepada kepuasan pelanggan. Pelanggan akan memberikan apresiasi positif bila langkah ini dilakukan. Yang masuk kedalam golongan ini (tanda panah ke bawah) adalah 1) harga obat, 2) Jadwal pelayanan, serta 3) biaya.

Menurut metode QFD, maka prioritas perbaikan untuk atribut persyaratan teknis adalah:

- Kecepatan dan ketanggapan dokter

- Perhatian dan kesabaran perawat

- Pengetahuan dan skill medis

- Kesabaran dokter

- Kecakapan dalam asuhan keperawatan

- Kemampuan bekerjasama

- Adanya reward dan punishment

- Reputasi yang baik
- Peralatan medis yang modern

- Jadwal pelayanan yang tertib

- Sistem administrasi lebih mudah

- Parkir luas, aman dan nyaman

- Ruang tunggu dan ruang periksa yang nyaman

- Penampilan profesional

- Harga obat yang rasional

- Biaya pelayanan

SARAN

Berdasarkan hasil dan kesimpulan penelitian maka dapat diajukan saransaran penelitian sebagai berikut :

1) Dengan mengetahui karakteristik pelanggan yang selama ini memanfaatkan jasa pelayanan rumah sakit, maka rumah sakit dapat menentukan pelayanan medis yang tepat terhadap segmen pasar yang bersangkutan. Hal ini akan dapat membantu rumah sakit untuk memuaskan pasiennya secara lebih efektif, menjamin mereka kembali dan menciptakan loyalitas pelanggan.

2) Perbaikan atribut persyaratan teknis agar sesuai dengan persyaratan pelanggan perlu menjadi perhatian utama. Atribut persyaratan teknis yang perlu diperbaiki dalam rangka meningkatkan kepuasan pelanggan dilaksanakan menurut prioritas dan ketersediaan sumberdaya yang ada di rumah sakit. Proses perbaikan ini bisa dilaksanakan secara bertahap dan terjadwal, dengan melibatkan seluruh sumberdaya dan elemen yang dimiliki rumah sakit.

\section{DAFTAR PUSTAKA}

Amihud Hari et al, Lessons Learn From the Applications of QFD to Definition of Complex Systems, Proceedings of the 16th Symposium of the INCOSE, Orlando, FL, 2006

Bouchereau, Rowland, Quality Function Deployment : A Comprehensive Literature Review, International Journal of Data Analysis Technique and Strategies, Vol 1 Issue 1, 2008

Cohen dalam Jui-Chin Jiang et al, Quality Function Deployment (QFD) Technology Designed for Contract Manufacturing, The TQM Magazine, Vol. 19 Iss. 4 p.291-307 
Direktorat Jenderal Bina Upaya Kesehatan, Data Rumah Sakit Online, http://.202.70.136.52/rsonline/report/r eport by catrs.php

Direktorat Jenderal Bina Upaya Kesehatan, Data Rumah Sakit Online, http://202.70.136.52/rsonline/report/r ekap kunjungan rs prop.php

Fitz-Enz, Benchmarking Staff Performance : How Staff Departments Can Enhance Their Value To The Customer, -Jossey-Bass Publishers, 1993

GarvinPerspectives on Quality , http://maisqual.squoring.com/wiki/i ndex.php/Garvin_Perspectives_on_Q uality, diakses tanggal 28 Oktober 2013

International Journal of Applied Strategic Management: Volume 1 Issue 1 page 4, diakses di : http://www.managementjournals.co m tanggal 20 Oktober 2013

Kabir, Carlsson, Service Quality : Expectations, perceptions and satisfaction about Service Quality at Destination GotlandA Case study, Gotland University, 2010

Lele, Sheth, The Customer Is Key: Gaining An Unbeatable Advantage Through Customer Satisfaction, John Wiley \& Sons Inc, New edition, 1991

Lewis \& Boom, dalam Kuruuzum, Koksal, The Impact of Service Quality On Behavioral Intention In Hospitality Industry, International Journal Of Business And Management Studies, Vol. 2, No. 1 , 2010

Massie, Essentials of Management, Prentice Hall Of India, 1987

Mayank Maewell, Patrick Dumas, Quality Function Deployment:Healthcare Imrpovement, Faculty of Worcester Polytechnic Institute, 2012, p.7

Mazur, History of QFD, QFD Institute, http:// www.qfdi.org/what_is_qfd/history_o f_qfd.html diakses tanggal 29 Oktober 2013
Mazur, Voice Of Customer Analysis : Modern System of Front-End QFD Tools, With Case Studies, 1996

Parasuraman, Zeithaml, Berry, SERVQUAL: A Multiple-Item Scale for Measuring Consumer Perceptions of Service Quality, Journal of Retailing, Vol. 64, No. 1, 1988

Peraturan Menteri Kesehatan Republik Indonesia Nomor 159b/Men.Kes/PER/II/1988 pasal 9

Quality Function Deployment...The Voice Of The Customer

http://www.themanagementor.com/e nlightenmentorareas/mfg/qm/qfd.ht m diakses pada 29 Oktober 2013

Roemer, Friedman, Doctors in Hospitals: Medical Staff Organization and Hospital Performance. Johns Hopkins Press, 1971

Senot, Claire, Aravind Chandrasekaran, Peter T. Ward, and Anita L. Tucker. The Impact of Conformance and Experiential Quality on Healthcare Cost and Clinical Performance. Harvard Business School Working Paper, No. 14-024, September 2013

Stahl, Bounds, Competing Globally Through Customer Value: The Management of Strategic Suprasystems, Quorum Books, 1991

Supranto, Pengukuran Tingkat Kepuasan Pelanggan, 2001, hal. 233

Total Quality Management, http://www.economist.com/node/143 01657, diakses tanggal 28 Oktober 2013

Verma, Services Marketing: Text and Cases, Second Edition, Pearson Education India, 2011

Wyckoff, D.D. (1992) 'New tools for achieving service quality' dalam C.H. Lovelock (ed.) Managing Services: Marketing Operations and Human Resources (2nd edition), Prentice Hall

Zultner, Business Process Reengineering With Quality Function Deployment, Zultner \& Company, Princeton, NJ, 1995 